\title{
Ecolinguistic Problems \\ of the North Caucasus \\ in the Context of Language Policy
}

\author{
Aysa I. Khalidov* \\ Chechen State Pedagogical University \\ 33 Kievskaia Str., Grozny, 364907, Russia
}

Received 13.12.2016, received in revised form 26.12.2016, accepted 15.01.2017

The paper is devoted to the study of language ecology of the North Caucasus in the context of language policy. The following problems have been identified among the main ecolinguistic issues: many languages of the peoples of Russia are facing the threat of extinction or are endangered; the actual ethnic composition of the population and the number of languages in the country have not been identified yet; in the conditions of irresistible globalization there is little chance of small ethnic groups' languages survival, the groups having neither written language nor the language of official status; ethnicity is doomed to extinction as their language is falling out of use, yet it is the main bearer of the cultural code of the people. The paper concludes that the threat to the Russian language and culture from other peoples and their cultures seems exaggerated. In relation to the urgency of preserving the Russian language as the state language and the language of interethnic communication in the country as a whole as well as in the republics, it is vital to consider the importance of preservation of all the languages spoken by the peoples of Russia and create the conditions for their further development.

Keywords: language, languages of the peoples of the Caucasus, language situation, the ecology of language, language policy.

DOI: 10.17516/1997-1370-0003.

Research area: philology.

Despite a growing number of works on the problems of ecology of the "small" and "big" peoples' languages in the Russian Federation as a multinational country, there are still questions for which no articulate answers have been given. Beyond the borders of our country, especially in Europe and the United States, protection and preservation of language issues is a subject of discussion and study for international and governmental organizations and scientific community. In our country these issues are a matter of responsibility for those who are far from science (at least from linguistics and ecolinguistics, in particular). Moreover, even the experts often sacrifice scientific objectivity for political considerations and interests of their ethnic group. So, there is no doubt that the discussion of the problems remains urgent and necessary since it is impossible to develop a proper

(C) Siberian Federal University. All rights reserved

* Corresponding author E-mail address: aisa@mail.ru 
national language policy, meeting the interests of all ethnic groups, without it.

Ecolinguistic problems of the North Caucasus have already been considered in a number of the author's previous publications (refer to (Khalidov, 2012 2 ; Khalidov, 2012 ${ }_{3}$; Khalidov, 2013 ; Khalidov, 2013 ${ }_{2}$; Khalidov 2014)). Thus, the purpose of this article is to generalize the observations and conclusions contained therein and identify the current situation in the whole region in the context of its defining language policy.

1. The complexity and urgency of the problem of ecology of languages in multi-ethnic and multi-lingual Russia are due not only to the fact that many languages of the peoples of Russia are facing a threat of extinction or are endangered and the fact that the country provided the greatest contribution to the well-known Atlas of the World's Endangered Languages (UNESCO), but also because of the fact that the actual ethnic composition of the population and the number of languages in the country (the USSR and Russia) have not been identified in either Soviet or Russian statistics and sociolinguistics for a long time. The All-Union population census of 1989, as is known, indicated 128 nationalities in the Soviet Union (including 14 union republics, which became independent states after the collapse of the Soviet Union). In 2002, $182(+54)$ nationalities were counted in Russia alone. It is clear that the ethnic composition of the population has not changed so much over 13 years: the increase of the population can be assumed, but the number of ethnic groups cannot grow by that. The principle of carrying out the census and counting the results has changed. The emergence of the 54 more nationalities on the ethnic map (under the assumption that the number of 128 also extended to the RSFSR (the Russian Soviet Federative Socialist Republic)) is explained, in particular and especially by the fact that the ethnic groups previously identified as a part of other nationalities were now defined as separate ethnic groups. For example, the Avars are divided into 10 nations speaking Avar-AndoTsez languages; the Dargin ethnic group was first identified as that of the Kubachins and the Kaytags, and then the Dargins were divided into many ethnic groups (for example, up to fifteen languages are identified in a place of one Dargin language). Yet, the most difficult ethnolinguistic situation is in Dagestan: 26 languages and peoples are usually numbered here. However, it was pointed out that this number may increase significantly. This is true for the current situation. Whether the number of languages and peoples is growing is another question, but artificial splitting of Dagestan languages is in progress. This is partly done on linguistic grounds (taking the significant differences between the dialects into account), but mostly under the pressure of the community leaders concerned about the fate of their "sub-ethnic groups". To some extent, this is a problem of many North Caucasus republics and peoples. For example, the Akkins, representatives of the Chechen sub-ethnos, speak of their language independence. However, this problem is the most serious for the Dargins in Dagestan. Until recently, it was believed that the Dargin language is a language of one of the largest Dagestan peoples which is spoken by about half a million of residents of Dagestan. Recently, however, more and more researchers are inclined to believe that, in fact, the single Dargin language does not exist: what is called the Dargin language is a group of no longer dialects but languages. From their point view, being probably a single Dargin language once, the dialects themselves disintegrated about two thousand years ago, and nowadays the relationship and similarity between them is distant. Indeed, according to the experts in the Dargin language, the Dargins, living in different regions of Dagestan, have difficulties in understanding the languages of each other, and it 
is possible that the experts who divided the Dargin language in already two dozen of languages are right. However, the trend when yesterday's dialects of one language are declared independent languages on a smaller basis than the Dargin language is becoming more and more common not only in Dagestan, the trend being dangerous primarily for these "new" languages themselves. In the conditions of irresistible globalization there is little chance for the small ethnic groups' languages survival, the groups having neither written language nor the language of the official status. Even in case of creating the system of writing, these ethnoses will be the ethnoses with the languages that have recently acquired their written form. Acquisition of an official status is more problematic than the adoption of writing as it is not enough to proclaim such a status. This requires the conditions for its implementation, which, of course, are not acquired with the declaration of status). Accordingly, the languages spoken by hundreds of thousands and millions have a better chance for survival.

2. It is not the only fact that makes ethnolinguistic situation in Russia complicated. The matter is that the USSR lacked the well thoughtout national language policy focused not on the assimilation but on the development of the languages of all the peoples of the country, especially of Russia as its bigger part, the policy that would not cause any irritation of either the Russians as the most numerous ethnic group or the rest of the peoples of Russia. A lot has been written about that but it is hardly possible to be sure, that appropriate policies are developed and introduced in Russia today. Serious efforts are made in this direction, but they are often subject to solving the problems of particular languages and peoples rather than achievement of equal rights and opportunities for all of them. It is unlikely that language problems in the country can be identified and solved the way A.V.
Kravchenko, one of the researchers in the field of ecolinguistics, sees the language policy. He is not the only one who exaggerates a possible threat to the Russian language coming from other ethnic groups of Russia. Starting with a perfectly correct assessment of negative processes related to "disengagement of the society and state from their control of the language environment", "change and even the loss of universal human values and cultural orientations", "lack of any language policy supported by the government" in modern Russian society in which "swearing has become the norm of young people's everyday life", A.V. Kravchenko brings it all to the threat to the Russian people and the Russian language by other ethnic groups and their languages: "If the society does not realize the urgent need to address the problems of language ecology and appropriate language policy elaboration at the state level in the near future, it may be too late: the final rejection of universal human values will take place, the regression of social consciousness will escalate, progressive economic decline will end with the surrender of political positions, the country will de facto become an underdeveloped country and face a direct threat of disintegration and absorption by other ethnic groups" (Kravchenko, 2011, p. 27). The decision, in his opinion, should be the following: "To avoid this, you need 'to actually and officially turn the Russian language into a national value. We need coordinated efforts of the government and society to improve the language environment on which, ultimately, preservation of the Russian culture and the Russian super-ethnos depends" (Ibid., p. 28). That is right, but should it be associated with "the decline in the quality of the language environment" fraught with the danger for the Russian language, with "disintegration and absorption by the other ethnic groups"? Nobody argues that "the coordinated efforts of the society and the government are needed to improve the 
language environment ", but does it follow that the efforts should be directed at combating "the absorption of the country" by other ethnic groups except for the Russian ethnos? Improvement in the country's language environment can occur if Kravchenko and his supporters understand the following. Firstly, there is no threat to the Russian language from the languages of other peoples of Russia. Secondly, the tendencies of the language development clearly indicate that the Russian language is and will remain the national language and the language of communication of the RF peoples, and no language is going to "intercept" this function. Thirdly, if there is somebody or something that the Russian language should be protected from these are primarily swearing and inarticulateness of not only the youth but well-known people in politics, culture and even science. It should be protected from not even awkward but dangerous reforms carried out in education within the last decade, the reforms recommending dictionaries and reference books of poor quality for educational institutions. It should be also protected from those who take care of the Russian language but can neither speak Russian nor write in it according to a proper style and spelling and grammar norms. Fourthly, these are other languages, including those that legally have an official status in their republics but have acquired or are acquiring the features of minority languages in the course of the observed national language processes development, that need to be protected. Cultivating the idea of the "Russian super-ethnos", which hides an attempt to substitute the self-identity of all the peoples of Russia by the Russian identity, the desire to make one ethnic group from hundreds of others by erasing all national differences, narrowing everything down to the Russian culture and the Russian mentality is doomed to the result that the idea of the "American super-ethnos" led to, the result being an "ethnic melting pot". It would seem that those who are responsible for the national strategy and the country's national language policy, in particular, must understand this. However, "the forces who believe that linguistic and cultural Russification of national minorities will guarantee the country's stability and unity are beginning to win in Moscow". This does not mean that there are no politicians who understand that such an approach will have one of the two possible outcomes. It will either lead to worsening of relations between the federal center and the subjects of the federation, thus, hitting the country's stability and unity, or Moscow will achieve linguistic Russification but get a completely unexpected result. Instead of the newly acquired "Russian" population, the government will have millions of citizens who have lost their languages and, as a consequence, their national culture, but have not become the Russians. Switching to the Russian language does not mean a change of mentality, lifestyle, behavioral, spiritual values, and culture in general. This great amount of people stuck between their native culture which is lost and the Russian culture which is not adopted will be the main threat to Russia" (Kambolov, 2008). It is hard to say whether T.T. Kambolov is right. He believes that "the transition to the Russian language does not mean a change of mentality, lifestyle, behavioral, spiritual values, and the culture in general": after all, the changes in mentality and the rest are inevitable; but we cannot but agree with him in one thing, the thing being the impossibility for those ethnic groups who have lost their languages to ever become truly Russians. In this regard, it is appropriate to refer to D. Joseph, who noted that "the most important of all allegations concerning the national identity is the assertion that the identity is actually fixed and given, it is actually predetermined by birth and remains essentially unchanged throughout our life" (Ibid.). Perhaps, over the time, in the course of more than a decade 
or even a century, the language change will lead to changes in mentality and in everything that is associated with the ethnic identity, but at what cost? How do those seeking to tear off "other" peoples from their languages and cultures imagine that? This will not be a painless process as, according to E. Hobsbawm, "an involuntary change of language of the national linguistic homogeneity in multi-ethnic and multi-lingual areas can be only achieved by massive coercion, expulsion or genocide" (Ibid.). Expulsion and genocide of nearly two dozens of peoples are impossible in our multinational country (even the Soviet "Great Helmsman" with his sadistic "migration policy" failed to do that to the full extent). "Mass coercion" that some forces that exaggerate the threat to the Russian language and culture from other peoples and their cultures are trying to give impulse to is also unacceptable in either overt or covert form.

3. The national-Russian bilingualism, cultivated since the Soviet times, undoubtedly has some positive effects along with negative effects, which have recently become much written and spoken about. It is clear that with all its positive aspects bilingualism has a downside as it leads to minoritarization of other languages except for Russian. In any Russian republic the Russian language performs the maximum number of public functions and has actually replaced the "local" languages from all spheres except for family communication and a monolingual environment. This is the reason to speak about a serious danger to the Caucasian and other national languages in the Russian Federation. According to S.A. Starostin and S.A. Burlak, who mean 'national-national' bilingualism but not 'nationalRussian' bilingualism as it can be understood from the context, "at the stage of bilingualism, when there are mixed villages and even mixed families of native speakers of languages I and II, everybody speaks both languages as their native languages since childhood. If no immediate actions are taken to oust language II from all the spheres of communication to whatever extent it is possible, language I is doomed" (Starostin, 2001, p. 66). Later, the same authors mentioned linguistic nihilism formed by bilingual dynamics and caused by a purely pragmatic approach to the choice of language of communication: "It is the language which is more beneficial that is chosen out of the two languages. Both parents speak not their "ethnic" language, but the one which is more beneficial with their children" (Starostin, Burlak, 2005, pp. 69-70). In the end, this inevitably leads to a complete exclusion of an "ethnic language" of all spheres of communication, including oral communication in the family and with the ethnic group representatives, which inevitably leads to the language extinction followed by the extinction of the entire ethnos. If this can happen at mixing the Avar and Dargin, Kumyk and Chechen, Kabardino-Cherkess and KarachayBalkar languages, for example, then the "nationalRussian" bilingualism definitely leads to these serious consequences. Such is the objectivity which is pointless to deny.

Dynamic development of the "nationalRussian" bilingualism for decades is not an accidental phenomenon. Objectively, it was supposed to develop even without state regulation: from the beginning of the national language "construction" in the USSR it was clear that there is no alternative to the Russian language as a language of international communication and the main language of record keeping, education, etc. Yet, the development of bilingualism at the expense of native languages resulted from a deliberate policy of ethnic and linguistic assimilation that started at the end of the $30 \mathrm{~s}$ in the last century. This is a "result of the language policy in education that started on March 13, 1938, the date of the Resolution of the Central Committee of the CPSU (The Central Committee 
of the Communist Party of the Soviet Union) "On compulsory study of the Russian language in schools of national republics and regions". The resolution dramatically changed the language policy: the entire territory of the USSR set a course for Russification, a gradual transfer of all schools to the Russian language as a language of teaching and learning, while the native language was studied as just one of the subjects" (Mestnikova 2010, p. 227). The resolution was not just about the introduction of the Russian Language as a compulsory subject in all schools of the country which, of course, was objectively necessary. The fact is that it laid the foundation for the replacement of multiple languages while learning one language, the language being Russian. Limitation of functions of "local languages" in education, which did not get much support only in a few former Soviet republics (Georgia, Armenia, the Baltic republics), naturally led to their control in other areas. In other words, the languages had been losing their positions of the most important determinants of ethnonational identity for decades, and many of them became endangered. [It should be noted that recently there have been attempts to somehow distract the attention from the language as an ethno-national identity determinant by substitution or devaluation of the concept of the "native language", in particular: "As you know, the 2002 census questions about the language concerned only the language skills (9.1. Do you speak Russian?; 9.2. What other languages do you speak?). The issue of a mother tongue in the census put aside and that caused numerous discussions at the time, including an expression of doubts in a scientific reliability of official data on the language situation, based on a specific understanding of the "native language" category and its subsequent interpretation. Socio-political discourse of this concept goes deep into mental constructs of ethno-national identity, concealing a high level of linguistic assimilation in favor of the Russian language. The lack of cultural-anddistinguishable approach to identification of the native language as a human's linguistic characteristic feature apparently implied identification of the language situation only and did not concern the question of national selfconsciousness" (Ibid., p. 226). The concept of "the second mother tongue" (and even "the third mother tongue"), insistently imposed in the course of the last decade, proves that "nonRussian nationalism" is being suppressed; what is more, "Russian nationalism" is gaining its strength again, which will cause a corresponding reaction from other ethnic groups. In this regard, we cannot but agree with V.V. Tishkov's assessment of the ethno-political situation in the country he set out in the conclusion of his major work published almost twenty years ago: "The peoples inhabiting Russia are not in a state of collapse or a "600-year war" with each other. From an ethnocultural point of view, the situation, including that of the recent years, seems to be much more favourable than in many other world major countries with multi-ethnic population. The all-Russian socio-cultural and civic community has a high degree of homogeneity based on the inherited egalitarianism, cultural and linguistic assimilation or multiculturalism based on the Russian language and culture, rather centralized system of economy and management. It is more likely that Russia faces not a "clash of civilizations" but what Sigmund Freud called "the narcissism of small differences". Contradictions, xenophobia, violence occur because of elite projects, ethnic entrepreneurship, struggle for power and resources, collective and personal rivalries. The ethnic often serves the basis for mobilization, arguments for negotiations or exit from a legal space and the society's social control" (Tishkov, 1997, pp. 526-527). However, we cannot agree with Tishkov that the ethno- 
political situation in Russia was more favourable than in other world multi-ethnic countries during the time when Tishkov's book was written and published (second half of the $90 \mathrm{~s}$ in the last century), and it is unlikely that the crisis of those years has been overcome. Nowadays, the problem of "Russian nationalism" is more relevant than the problem of "non-Russian nationalism", the problem blowing up in the $90 \mathrm{~s}$, which is emphasized by Tishkov himself (Ibid., p. 121). In the early 2000s the spreading "street" "Russian nationalism", which was not much restrained by the authorities, was replaced by an unpredictable in its consequences turn in the development of the state national policy strategy aimed at uniting hundreds of ethnic groups of the country not into a "multinational people of the Russian Federation", as they are specified in the Constitution, or a "multi-ethnic community of the Russian peoples", but the "Russian nation", the "multinational Russian nation" (refer to (//http://azerros.ru)). One of the main points of the proposed national policy strategy was "preservation of the Russian cultural dominant with all the nations of the Russian Federation being its medium as this dominant is formed not only by the ethnic Russians, but also incorporates the culture of all the peoples of Russia". In fact, the idea should have been formulated as the "development of the all-Russian cultural dominant, formed by all the peoples of Russia", as the Russian cultural dominant (not culture in general, but the dominant) is formed by the ethnic Russians, and representatives of other nations (both from Russia and many other countries) took part in it. But for all that, the Russian culture did not absorb the cultures of other peoples of Russia, it incorporated the elements of other cultures, having done this the same way other non-Russian cultures incorporated the elements of the Russian culture. These and many other formulations of the national policy objectives of the project did not mean the development of a balanced bilingualism, harmonious development of languages and cultures of the peoples of Russia. They were introduced to replace the concept of "Russian civil identity" with the concept of "Russian national identity" and since we are talking about national identity, the next step, apparently, will be the replacement of the first component of the phrase ( $\rightarrow$ "Russian national identity"). If the developers of the "Strategy" had really stuck to the idea of "building a multicultural nation on the basis of the citizens' double and not mutually exclusive identity (cultural-and-ethnic and stateand-civil) as the most constructive formula of new Russia" (Ibid.), the "Strategy" project would have been radically different. Yet, the idea of assimilation of all the non-Russian peoples of Russia (including assimilation through the stimulated extinction of their languages) was clearly traced, the idea being inherited from the national policy of the no longer existing Soviet government. The finally adopted strategy of the state national policy of the Russian Federation for the period up to 2025 (approved by the Presidential Decree No. 1666 dated December 19, 2012) is positively different and satisfies those who do not share the initial "conception" of the original project. Still, one can hardly say whether it is implemented in strict compliance with its real content and requirements.

4. The tendency towards gradual "extinction" of the languages of the peoples of the Soviet autonomies was accelerated by a radical turn in understanding the objectives of the national language policy encouraged by the linguists in the 50s. Russian social linguistics, that was on the edge of its formation, came to the following conclusion: "The practice of previous periods of the Soviet society development has shown that in terms of social development the potential of the USSR small nationalities' written languages is limited and does not respond to this new phase 
of increased spiritual and material needs of their medium. The latter were convinced that further successful and comprehensive development is possible only through the Russian language, since their secondary and special, as well as higher education is connected with the Russian language" (Sovremennaia..., 1984, p. 121). Generally, the conclusion is not that controversial: hardly anyone would argue the fact that the Russian language occupies a leading position in education, and it should keep this position. However, the fact is that national sociolinguists did not stop there. Justifying the feasibility of non-extension of the functions of the "small nations" " languages, the "small nations" being actually all the nations that do not form the Union republics, and reducing the functions performed by them by that time, in 1957-1958 they started discussing the problem of correlation between the scope of language functions and vocabulary development, especially scientific and technical terminology and classification of languages as per their functional development prospects. After discussing the problem at the Scientific Session of the Division of Social Sciences of the USSR (Moscow, 23-26 June 1956), the linguists unambiguously attributed the languages of the autonomous regions to the second group - a group of "unpromising" languages. Of course, not all the participants of the scientific forum shared this opinion. Some of them "favored the expansion of the functions of these languages to the functions of such most developed national languages of the Union republics as Ukrainian, Armenian, Georgian, Azeri and others". In particular, they raised the question "about teaching in the sphere of higher education and publication of scientific literature on all fields of knowledge in these languages". But their voices drowned in a stream of talks that welcomed a "drastic limitation of functions of these languages" (Desheriev, 1966, p. 11). Since that time, the fate of literary languages of the peoples of autonomies in Russia and autonomies in other Soviet republics was decided. In their further "development" the languages were approaching a threshold after which the language would not have any chance to be preserved.

5. Heading towards a systematic reduction of the functions, or, to put it bluntly, to the "strangulation" of the majority of languages in the vast country started on the background of a global process of language extinction, which does not slow down until today. The attitude towards this process in the society and among linguists is mixed. Some politicians, public figures, even scientists think that the situation is exaggerated, because it is a natural process which we are still unable to prevent, and can only accept the fact that, in the end, only a few languages would remain on earth (and it will probably be only English), the languages being completely satisfying for the people's communication needs and professional activities. This means that from the two codes defining the ethnos - cultural and biological - the human community will lose the first one, and it is hardly possible to be sure that the biological code will keep ethnic diversity in the world. In case only the "biological code" is preserved ethnicity is doomed to die out together with their language which is the main medium of a cultural people. If we do not realize it and start undertaking some actions from the moment of the first symptoms of language (and consequently the culture) minoritarization, the process may turn to be irreversible at some point, and in the best case the language will be only fixed for its descendants to study. The reason for concern of many peoples of Russia, especially the peoples of the North Caucasus, is the inclusion of almost all languages of the peoples of the North Caucasus in the list of endangered languages in the Atlas of the World's Languages in Danger. There are other issues which the author dwelt 
upon (Khalidov, 2014 $)$ : how valid is it? does the decision correspond to the criteria adopted by the UNESCO experts. Yet, there is no doubt that the majority of languages of the peoples of the North Caucasus have the prospect of becoming a minority. It is obvious to everyone familiar with the major works on the subject (please, refer to: (Fill, 2001; Haugen, 1972, 2001; Krauss, 1992; Trampe, 2001, et al.) A.E. Kibrik and other authors identify "sick" languages of Dagestan among the languages of the peoples of the Caucasus, placing them between "healthy" and "dead" ones. These are the Hinuq, Hunzib, Archi, Godoberi, Kryz, Udi, Tsez, Khwarshi languages. If a minority language is a language "developing" in the direction of its disappearance, "flatting" (music. Minor - "musical harmony, chord which is built on the minor third"), then many other languages, not included in the list by A.E. Kibrik, are likely on the same path.

6. According to Z. Gabunia and R. Tirado Guzman following M. Krauss, the languages disappear because of natural and unnatural causes.

There is one natural cause of gradual dying out and eventual disappearance of a language. It is the increasing differences between the dialects and their separation to the point where they become independent languages. Presumably, it happened when a single Nakh language was divided into three languages - Chechen, Ingush and Bats (Tsova-Tushino). Some Dagestani languages are on the same path. These are primarily Dargin, which has already started splitting up into half a dozen languages, and Avar. The concepts of "dying out" and "disappearing" in this case are relative: the complete disappearance of the language does not occur because each language formed on the basis of a common language preserves many features of the original language.

The unnatural causes of minoritarization and even complete disappearance of languages are quite numerous. These are: 1) natural disasters, catastrophes, 2) wars, 3) the dominance of one language over another, including the negative language policy in a multiethnic state, 4) the natives' contempt for their own language (linguistic nihilism); 5) migration of a significant or the most part of the representatives of the people from their historical homeland; etc. (Gabunia, Tirado Guzman, 2002, pp. 8-9). From these five reasons mentioned above, four can be related to, for example, the Chechen language (reasons 2, 3, 4 and 5); as for the other peoples of the North Caucasus, the first two are not relevant for them and the third one is not as relevant as for the Chechens, regardless the mono-ethnicity of the population of the Chechen Republic and an obvious trend towards the expansion of the social functions of the Chechen language in the course of the last two decades. However, the position of all the languages of the peoples of the North Caucasus and Russia are gradually weakening for reasons 4 and 5. The analysis of the functional scope of a written form of the languages of the peoples of the Caucasus proves extreme limitations of their functions in comparison with the functions of the Russian language, dominant in all the areas, except for everyday life. What aggravates the situation is the fact that the native language as a school subject is not sufficient for a satisfactory mastering of the written system of the language due to a limited number of academic hours. Moreover, the republican periodical press in a native language is not "prestigious" that leads to its small circulation. The main area of use of the languages of the peoples of the Caucasus was (and still is for many languages) the scope of communication in the family and a monolingual environment, that is the area where oral, spoken form of the language is used, though even in this area the use of the native language in some regions is minimal. It is only recently that the tendency to strengthen the functions of the native languages 
in a few areas, where they could and should be leading or, probably, the only ones, is turning to be evident. For example, in the Chechen Republic "the sphere of family relations is one of a few where there have been changes in the distribution of the Chechen and Russian languages in favor of the former" (Iakh'iaeva, 2007, p. 96), although, it is early to conclude about the displacement of Russian from the communication in the family and monolingual environment. If we take into account the so-called intercalation (inclusion of words and phrases of the Russian language in the Chechen speech with the equivalents available in the Chechen language: Nachal'nik uchastka bolh bira tso; Govoriat h'o mare iahana, $i$ hIumma a ne govorish? Hio sotsa idesh zachet sdavat'? Chetvertyi etazh tIeh zhit' desh vu $i z a$ ), that was considered by Iakh'iaeva, there is a reason to assume that there is an opposite phenomenon - the displacement of the Chechen language of everyday life communication. With some variations, this situation exists in other North Caucasus republics, and its preservation can mean the prospect of a complete loss of their national languages

7. "One of the major problems slowing down the process of literary language formation is its terminology base underdevelopment" (Khalidov, 2012 2 , p. 36). Meanwhile, due to the limited functions of the languages of the peoples of the North Caucasus, the development of terminological systems was slowing down, even in some human sciences and disciplines. Technical terminology in natural and technical spheres was hardly formed. The current situation in terminological systems of the languages of the peoples of the North Caucasus is, presumably, the same as it is described for the Chechen language (Grammatika..., 2013, p. 126). Many definitions of not strictly scientific application remained unmarked with the nominations from the resources of the native language, but the overall scale of borrowings from Russian (and through Russian) and other languages was not systemic and did not lead to the formation of own terminological systems. A large share of foreign words in the native language and a progressive nature of this process are a phenomenon that cannot be characterized explicitly. On the one hand, it is hardly reasonable to prevent borrowings, especially in the area of terminology: even in the Russian language, a language of science for hundreds of years, scientific, scientific-technical, military, engineering, and other terminology systems were largely formed on the basis of the borrowings and it is not considered a sign of the "penury" of the Russian language. On the other hand, some borrowing limitations must be set: if a language has its own resources for the formation of terminology, they must be used as much as possibl, to introduce their own terms (form new use of common vocabulary in the terminological sense). This approach has been applied by the compiler of the "Glossary of Linguistic Terms of the Chechen language" (Khalidov, 2012), which contains about 1,000 terms.

8. The language situation in the North Caucasus is now somewhat different from that of twenty or more years ago. The problem of "reverse" ("Russian-national") bilingualism is less urgent, the problem being a considerable number of the Russian population in the republic who influenced an active use of a native language by the rest of the population: the number of the Russian-speaking population in some republics has significantly decreased, and in this regard, the factor of the language environment has also decreased. The Russian population in Chechnya, for example, has decreased by dozens of times which is due to the well-known events on its territory. The share of Russian population in neighboring Ingushetia is quite low. The population structure in other North Caucasus republics has significantly changed. It is clear that new circumstances require different 
approaches and principles for the development and implementation of the language policy as well as concrete programs in language life which are aimed at immediate prospects and more distant future. In particular, it is necessary to somehow compensate for the language environment factor reduction and take steps to prevent a sharp decline in the level of mastering of the Russian language in our republics.

9. While developing and implementing the programs that favour the conditions for normal functioning of the Russian language in the North Caucasian subjects of the Russian Federation and in the country as a whole, we must realize the importance of preserving all the languages spoken by the peoples of Russia and create conditions for their further development. There is no doubt that it is necessary to maintain the status of the Russian language as the official language and the language of the interethnic communication in the country and in the republics. Russian is an important tool without which these people do not have access to full education, especially higher education, and to all sources of all sorts of information. However, such an attitude towards the Russian language should not prevent us from forgetting the fact that "language in the ethnic boundaries of its native speakers is not only and not so much a means of communication, but the people's memory and history, their culture and experience of cognitive activity, philosophy and psychology, the generation-to-generation knowledge about nature and cosmos, diseases and ways of treating them, education and upbringing of new generations in order to preserve and ensure the growth of their ethnos and ethnic identity. Thus, language is a form of culture which embodies the emerging national historical type of life in all its diversity and dialectical contradiction" (Tarlanov, 2005, pp. 623-624). It does not matter how much a person speaks a particular language, "any language is an expression of each community's uniqueness, a certain way of perceiving and describing their reality. Consequently, each language must be provided with all necessary conditions for its functions development and performance in all their forms. Every linguistic community has the right to create the conditions and involve a variety of domestic remedies in order to guarantee the use of the language in all social spheres" (Vsemirnaia declaratsiia..., 1996). Having such a right, our people have never had the conditions for its implementation; their language functions have always been limited. In a situation where the "language of a more numerous people tends to expand its sphere of influence", which is expressed, for example, in the adoption of the federal target program "The Russian language", to raise the status of the Russian language in a federal state, "the language of a smaller nation has set the aim of mainly self-preservation" (Danesh, Chmeirkova, 1994, p. 29). Apart from adoption of the language laws in all the republics development of special programs is necessary in order to ensure such self-preservation. The programs should be based on understanding of the past and the present of the Caucasian peoples' language and cultural life and aim at identifying ways and means of solving the problems crucial for the these peoples. First of all, it is necessary to take measures to ensure that the functions of these languages in the family and mono-ethnic environment were not reduced, and no other language, including Russian, displaced them from those spheres of communication. Secondly, the native languages should be used more in education, in primary schools, in particular; etc. There are no grounds for concern about the fate of the Russian language in Russia; in any case, other languages are no threat to the Russian language, and an extension of their functions within the limits defined by their own abilities does not confront with the role of the Russian language as the national language of a 
federal multi-national and multi-ethnic state and will only lead us to a balanced national-Russian bilingualism. Such bilingualism has always been declared in the Russian social linguistics. Yet, was no real balance in it. Moreover, those whom the national language policy depended on did a lot for that balance to be never reached.

10. In recent decades there have been a lot of predictions about the future of the mono-lingual mankind. Whereas it was a dominant role of one or another language in different parts of the world that was previously spoken about; in recent years a special emphasis is given to the fact that only a few languages will finally remain on earth, or it will probably be only English (although it is unlikely because of its irregular spelling and grammar, to put it mildly), which will completely satisfy the people's needs for communication and professional activities. As for other languages, they are doomed to extinction as "useless" ones. In this context, it is vital to draw attention to the main reason of why no language out of hundreds of projects aimed at a universal language creation (and even Esperanto, the most successful language of them) was accepted by the humanity. Moreover, the reason is not only and not so much the national egoism but lack of prospects for such a universal language. Even in case of an unlikely transition to any (natural or artificial) universal language and the refusal from native languages this language will first break into dialects, then the dialects will shape into languages, and, thus, mankind will come to the same multilingualism which it tried to escape from. And this will happen in no more than hundreds of years, if not earlier.

\section{References}

Burlak, S.A., Starostin, S.A. (2005). Sravnitel'no-istoricheskoe iazykoznanie [ComparativeHistorical Linguistics]. Moscow, Academia, 432 p.

Danesh, Fr., Chmeirkova, S. (1994). Iazyk - kul'tura - etnos [Language - Culture - Ethnos]. Moscow, Nauka, 233 p.

Desheriev, Iu.D. (1966). Zakonomernosti razvitiia $i$ vzaimodeistviia iazykov v sovetskom obshchestve [Regularities in the Development and Interaction of Languages in the Soviet Society]. Moscow, Science, $404 \mathrm{p}$.

Fill, A. (2001). Ecolinguistics. State of the Art 1988, In A. Fill and P. Mühlhäusler (eds.). The Ecolinguistics Reader: Language, Ecology and Environment. London and NewYork, Continuum, 43-54.

Gabunia, Z., Tirado Guzman, R. (2002). Minoritarnye iazyki v sovremennom mire. Kavkazskie iazyki [Minority Languages in the Contemporary World. Caucasian Languages]. Moscow, Iazyki slavianskoi kul'tury, $288 \mathrm{p}$.

Grammatika chechenskogo iazyka [Grammar of the Chechen Language] (2003). V trekh tomakh. Tom I [In three volumes. Volume I]. Ed. by A.I. Khalidov. Grozny, Groznenskii rabochii, $848 \mathrm{p}$.

Haugen, E. (1972). The Ecology of Language. Essays by Einar Haugen. Standford, Standford University Press, 368 p.

Haugen, E. (2001). The Ecology of Language, In A. Fill and P. Mühlhäusler (eds.). The Ecolinguistics Reader: Language, Ecology and Environment. London and NewYork, Continuum, 57-66.

Hobsbawm, E. (2005). Vse li iazyki ravny? Iazyk, kul'tura i natsional'naia identichnost‘ [Are All the Languages Equal? Language, Culture and National Identity], In Logos, 4 (49), 33-43.

$$
-36-
$$


Iakh'iaeva, A.A. (2007). Chechenskii iazyk v 90-e gody XX veka: funktsii i structura. Dissertatsiia na soiskanie uchenoi stepeni kandidata filologicheskikh nauk [The Chechen Language in the 90-s of the XX Century: Function and Structure. The PhD Thesis]. Grozny, 166 p.

Iartseva, V.N. (1993). O sud'bakh iazykov v sovremennom mire [On the Fates of the Languages in the Contemporary World], In Izvestiia RAN. SLIa [Bulletin of the Russian Academy of Sciences: Language and Literature], 52, 1, 3-15.

Joseph, J. (2005). Iazyk i natsional'naia identichnost' [Language and National Identity], In Logos, 4 (49), 4-32.

Kambolov, T.T. (2008). Kogda poiaviatsia osetinskie shkoly [When Do the Ossetian Schools Appear?]. Available at: //http://ironau.ru/kambolov-osradio.html (accessed 5 June 20016).

Khalidov, A.I. (2012). Glossary of Linguistic Terms of the Chechen Language. Grozny, 447 p.

Khalidov, A.I. (20122). Chechenskii iazyk i dialekty [The Chechen Language and Dialects], In Narody i kul 'tury. Chechentsy [The Peoples and Cultures. The Chechens]. Moscow, Science, 23-41.

Khalidov, A.I. $\left(2012_{3}\right)$. Ekologiia iazykov Kavkaza. Stat'ia pervaia: Vvedenie. Chechenskii iazyk [Ecology of the Languages of the Caucasus. Article 1: Introduction. The Chechen Language], In Bulletin of the Academy of Sciences of the Chechen Republic], 2 (17), 191-210.

Khalidov, A.I. (2013 $)$. Ekologiia iazykov Kavkaza. Stat'ia vtoraia: Abhazsko-adygskie iazyki [Ecology of the Languages of the Caucasus. Article 2: The Abkhaz-Adyghe Languages], In Bulletin of the Academy of Sciences of the Chechen Republic], 1 (18), 191-198.

Khalidov, A.I. $\left(2013_{2}\right)$. Ekologiia iazykov Kavkaza. Stat'ia tret'ia: Iazyki narodov Dagestana (dagestanskie iazyki) [Ecology of the Languages of the Caucasus. Article 3: Languages of the Peoples of Dagestan (The Dagestan Languages)], In Bulletin of the Academy of Sciences of the Chechen Republic], 4 (21), 70-81.

Khalidov, A.I. (2014 $)$. Obosnovano li vkliuchenie chechenskogo iazyka v Atlas of the World's Languages in Danger? [Is the Incorporation of the Chechen Language in the Atlas of the World's Languages in Danger Reasonabe?], In Sovremennaia nauka: aktual'nye problemy teorii i praktiki. Seriia Gumanitarnye nauki [Modern Science: Actual Problems of Theory and Practice. Series Humanities], 5-6. Moscow, 78-80.

Khalidov, A.I. (2014 $)$. Ekologiia iazykov Kavkaza. Stat'ia chetvertaia: problemy sokhraneniia i razvitiia neiberiisko-kavkazskikh iazykov narodov Kavkaza [Ecology of Languages of the Caucasus. Article 4: Problems of Preservation and Development of the Uniberian-Caucasian Languages of the Peoples of the Caucasus], In Bulletin of the Academy of Sciences of the Chechen Republic], 2 (23), 87104.

Krauss, M. (1992). The World's Languages in Crisis, In Language, 68 (1), 4-10.

Kravchenko, A.V. (2011). Ekologiia iazyka i iazykovaia politika [Language Ecology and Language Policy], In Aktual 'nye problemy filologii i pedagogicheskoi lingvistiki [Actual Problems of Philology and Educational Linguistics], Issue 13. Vladikavkaz, available at: http://isea.academia.edu/ AlexanderKravchenko

Leontovich, O.A. (2007). Vvedenie v mezhkul'turnuiu kommunikatsiiu [Introduction to Intercultural Communication]. Moscow, Gnosis, 368 p.

Mechkovskaia, N.B. (2001). Obshchee iazykoznanie. Strukturnaya i sotsial'naia tipologiia iazykov [General Linguistics. Structural and Social Typology of Languages]. Moscow, Flinta, 312 p. 
Mestnikova, A.E. (2010). Iazyki korennykh malochislennykh narodov Severa v zerkale perepisei naseleniia [Languages of Indigenous Peoples of the North in the Mirror of the Census], In Izvestiia Ural'skogo gosudarstvennogo universiteta [Bulletin of the Ural State University], 5 (84), 226-230.

Proekt 'Strategii gosudarstvennoi natsional'noi politiki Rossiiskoi Federatsii' [The "Strategy of the Russian State National Policy" Project] (2012). Available at: //http://azerros.ru (accessed 5 June 20016).

Sovremennaia ideologicheskaia bor'ba i problemy iazyka [Modern Ideological Struggle and Language Problems] (1984). Moscow, Science, 238 p.

Starostin, S.A., Burlak, S.A. (2001). Vvedenie v lingvisticheskuiu komparativistiku [Introduction to Linguistic Comparative Studies]. Moscow, Editorial URSS, 272 p.

Tarlanov, Z.K. (2005). Iazyk kak universal'noe sredstvo etnicheskogo samovyrazheniia i forma etnicheskoi kul'tury [Language as an Universal Means of Ethnic Expression and a Form of Ethnic Culture], In Izbrannye raboty po iazykoznaniiu ifilologii [Selected Works on Linguistics and Philology]. Petrozavodsk, Petrozavodsk State University, 621-627.

Tishkov, V. (1997). Ocherki teorii i politiki etnichnosti v Rossii [Essays on the Ethnicity theory and Policy in Russia]. Moscow, Science, 528 p.

Trampe, W. (2001). Language and Ecological Crisis: Extracts from a Dictionary of Industrial Agriculture [1991], In A. Fill and P. Mühlhäusler (eds.). The Ecolinguistics Reader: Language, Ecology and Environment. London and NewYork, Continuum, 232-240.

Vsemirnaia deklaratsiia iazykovogo prava. Stat'ia 7 [The Universal Declaration of the Linguistic Right. Article 7] (1996). Barcelona.

\title{
Эколингвистические проблемы \\ Северного Кавказа \\ в контексте языковой политики
}

\author{
А.И. Халидов \\ Чеченский государственный педагогический \\ университет \\ Россия, 364907, Грозный, ул. Киевская, 33
}

Статья посвящена проблеме изучения экологии языка народов Северного Кавказа в контексте языковой политики. Среди основных эколингвистических проблем выделены следуюшие: многие языки народов России подошли или подходят к грани исчезновения; до сих пор не определены реальный этнический состав населения страны и число языков в стране; в условиях непреодолимой глобализации невероятно мало шансов на выживание языков малочисленных этносов, к тому же бесписьменных и не имеющих статуса государственных; этнос обречен на угасание и вымирание по мере угасания своего языка, являющегося главным носителем культурного кода народа. В работе делается вывод, что угроза русскому языку и русской культуре со стороны других народов и их культур представляется преувеличенной. При важности сохранения отношения к русскому языку как общегосударственному, как к языку межнационального общения в стране в целом и внутри республик необходимо осознавать значимость сохранения 
всех языков, на которых говорят народы России, и создавать условия для их дальнейшего развития.

Ключевые слова: язык, языки народов Кавказа, языковая ситуация, экология языка, языковая политика.

Научная спеичиальность: 10.00.00 - филологические науки. 